\title{
Analysis by sex of low back pain among workers from small companies in the Paris area: severity and occupational consequences
}

\author{
Jacques Alcouffe, Patrice Manillier, Michèle Brehier, Claire Fabin, Françoise Faupin
}

\begin{abstract}
Objectives-To describe workers with low back symptoms, to identify risk factors and to assess the occupational consequences separately in men and women.

Methods-A descriptive study was conducted between 1 October 1996 and 31 December 1996 in a sample of workers selected at random from all types of small companies in the Paris area. A group of 202 occupational physicians interviewed 7129 workers with a standardised questionnaire including the Nordic question-

$(n=258)$ was not linked to sex, but only to aging and severity.

Conclusions-The incidence and severity of low back pain were higher in women, although they seemed to be less exposed to known occupational risk factors. However, our results indicate a preponderance of these risk factors among female workers. Particular attention must therefore be paid to lifting of weights and uncomfortable working positions in female jobs (clerk, trading, health care staff).

(Occup Environ Med 1999;56:696-701)
\end{abstract} naire. Data analysis was performed by sex in the two groups: with low back pain and without low back pain over the previous 12 months. The group with low back pain was then divided into four subgroups: mild cases (without referred pain), moderate cases (with referred pain above the knee), serious cases (with referred pain below the knee), and low back pain with occupational consequences.

Results-7010 questionnaires were able to be evaluated. The sample consisted of $54.8 \%$ of men (3842) and $45.2 \%$ of women (3168), with a mean age of 37.8 and 37.0 years, respectively $(p<0.05)$. The following risk factors occurred significantly more often in men: high weight, height, body mass index (BMI), smoking, number of children, increased driving time and work time, material handling tasks, uncomfortable working positions. Most women were clerks (53\%). Non-conditional logistic regression applied to the whole sample identified female sex as a risk factor (odds ratio $(O R)=1.85,95 \%$ confidence interval (95\% CI) 1.58 to 2.13 ). The following risk factors were common to both sexes: lifting weights $>10 \mathrm{~kg}$, in women (OR $1.69,95 \%$ CI 1.27 to 2.25) and in men (OR 1.27, 95\% CI 1.06 to 1.53 ), uncomfortable working positions (OR 2.04, 95\% CI 1.58 to 2.17 and OR $1.85,95 \%$ CI 1.69 to 2.43 ), and absence of means to achieve good quality work (OR 1.39, 95\% CI 1.19 to 1.63 and OR 1.38 , 95\% CI 1.15 to 1.65 ), respectively. Driving was a risk factor only in men and its importance increased with driving time (driving $>4$ hours a day (OR 1.61, 95\% CI 1.24 to 2.09 )). Severe low back pain was linked to female sex $\mathbf{( 1 0 . 2 \%}$ of women $v$ $6.6 \%$ of men), high BMI, aging, and uncomfortable working positions. Low back pain with occupational consequences
Keywords: low back pain; sex; severity

Low back pain is a frequent phenomenon found in every occupational category. Paradoxically, it has not been extensively examined in France. Several authors ${ }^{1-6}$ have reported that $>60 \%$ of the population had experienced at least one episode of low back pain during their lifetime.

In the French occupational health organisation, every worker, whether or not exposed to occupational hazards, undergoes a medical examination at least once a year, performed by their occupational physician. We took advantage of these systematic medical examinations to study low back pain among company workers in small companies in the Paris region. We have a privileged position as an observer of occupational health phenomena because every occupational physician is also required to study, for one third of their time, each worker's workstation. Our organisation consists of 350 occupational physicians (not all employed full time) who examine 800000 workers of the Paris region, at least once a year. These 800000 workers are employed in all job categories in the Paris area: trading, selling, clerking, production, manufacture, building, handling, cleaning, transport, research, teaching, and healthcare staff. These workers belong to companies employing 1-3500 workers, but the mean number of nine employees indicates that they are mostly very small. We decided to evaluate occupational factors associated with low back pain.

The study objectives were (a) to describe workers with low back symptoms (back ache, pain, discomfort), (b) to identify risk factors, and $(c)$ to assess occupational consequences.

The jobs occupied by men and women were very different. On the basis of the preliminary results, we found that the severity of low back pain and job category were strongly linked to 
sex: nurses and municipal employees. ${ }^{7}$ It therefore seemed necessary to reanalyse the data by sex, separating men and women.

\section{Methods}

POPULATION AND METHODS

A descriptive study was conducted in a randomly selected sample of workers, by means of an anonymous standardised questionnaire derived from the questionnaire of Collas and Mairaux ${ }^{8}$ and including a part of the Nordic questionnaire. ${ }^{9}$ Between 1 October 1996 and 31 December 1996, 202 volunteer occupational physicians interviewed the fifth worker attending their office for their annual systematic examination. One worker was therefore selected at random, each half day, out of 10 to 15 workers attending the surgery. The occupational physician read the questions to the worker and ticked his or her answers.

\section{DATA COLLECTION}

The first 15 questions described the worker and his work station according to known risk indicators reviewed by Riihimäki ${ }^{1}$ : sex, age, weight, height, right or left handed, number of children, smoking habits, regular physical exercise, driving time, job, duration of work time, work time a week, manual lifting of weights heavier than $10 \mathrm{~kg}$, uncomfortable working positions, and means to achieve good quality work. The 16th question, derived from the Nordic questionnaire was : "Have you ever experienced low back problems (back ache, pain, discomfort)?". If the answer was no, no further questions were completed. If the answer was yes, the occupational physician asked another 11 questions: pain with or without radiation, pain referred above or below the knee; admission to hospital for low back pain; change of job, change of work station, or work station enhancement; during the past 12 months: total duration of low back problems, reduction of work activities, reduction of

Table 1 Description of the sample

\begin{tabular}{|c|c|c|c|}
\hline & $\begin{array}{l}\text { Men } \\
(n=3842)\end{array}$ & $\begin{array}{l}\text { Women } \\
(n=3168)\end{array}$ & $p$ Value \\
\hline Age (mean) & 37.8 & 37.0 & $<0.05$ \\
\hline BMI (mean) & 24.6 & 23.3 & $<0.001$ \\
\hline Right handed (\%) & 87 & 90 & $<0.05$ \\
\hline Left handed $(\%)$ & 8 & 7 & $<0.05$ \\
\hline Ambidextrous (\%) & 5 & 4 & $<0.05$ \\
\hline Children (mean n) & 1.42 & 1.21 & $<0.001$ \\
\hline Smoker (\%) & 45.6 & 37.7 & $<0.001$ \\
\hline Regular physical exercise (\%) & 35.7 & 29.6 & $<0.001$ \\
\hline \multicolumn{4}{|l|}{ Driving time $(\% \mathrm{~h})$ : } \\
\hline Not concerned & 20.4 & 44.1 & $<0.001^{\star}$ \\
\hline$<2$ & 49.4 & 48.4 & $<0.001^{\star}$ \\
\hline $2-4$ & 19.9 & 6.4 & $<0.001^{\star}$ \\
\hline$>4$ & 10.3 & 1.1 & $<0.001^{\star}$ \\
\hline Main functions with handling component (\%) & 49.5 & 19.6 & $<0.001$ \\
\hline Qualified or management jobs (\%) & 67.9 & 34.8 & $<0.001$ \\
\hline Clerks (\%) & 12.0 & 53.0 & $<0.001$ \\
\hline Trading (\%) & 21.7 & 25.6 & $<0.001$ \\
\hline Health care staff (\%) & 3.2 & 8.7 & $<0.001$ \\
\hline Occupation (mean y) & 10.0 & 9.4 & $<0.01$ \\
\hline Worktime/week (mean h) & 42.8 & 38.0 & $<0.001$ \\
\hline \multicolumn{4}{|l|}{ Manual lifting of weights $>10 \mathrm{~kg}(\%)$ : } \\
\hline Never & 39.4 & 68.0 & $<0.001^{\star}$ \\
\hline$<$ Once/week & 12.4 & 10.0 & $<0.001^{\star}$ \\
\hline$\geqslant$ Once/week but not every day & 20.6 & 11.1 & $<0.001^{\star}$ \\
\hline Every day & 27.6 & 10.9 & $<0.001^{\star}$ \\
\hline Uncomfortable working positions (\%) & 34.3 & 31.9 & $<0.05$ \\
\hline Means to achieve good quality work (\%) & 74.6 & 73.3 & NS \\
\hline
\end{tabular}

^Overall comparison. leisure activities, consultation with health care providers, medication intake, duration of sick leave for low back problems, and type of compensation.

We compared the two groups (those who had experienced low back pain and those who had never experienced low back pain) for each of the first 15 questions, separately in men and women.

ANALYSIS AND STATISTICAL METHODS

We created two groups according to the answer to question 16: (1) without low back pain, (2) with low back pain. Only workers with low back pain during the previous 12 months were included in the analysis. We calculated the body mass index (BMI) - weight/height squared-in the two groups.

Group 2 (with low back pain) was then divided into three subgroups according to the answer to question 17 (a) low back pain without irradiation, called mild cases, $(b)$ low back pain with irradiation above the knee, called moderate cases, (c) low back pain with irradiation below the knee, called serious cases.

Independently of the severity of the low back pain already described, we created two other subgroups derived from group 2 (with low back pain): (a) low back pain with occupational consequences (change of job, change of work station, work station enhancement), (b) low back pain without occupational consequences.

Statistical analysis was performed with SPSS software. Qualitative variables were compared with the $\chi^{2}$ test, and quantitative variables by analysis of variance (ANOVA). Several nonconditional logistic regressions were performed to highlight the factors associated with low back pain, low back pain with radiation (combining pain referred above and below the knee), and occupational consequences. A $p$ value $\leqslant 0.05$ was considered significant.

\section{Results}

DESCRIPTION OF THE SAMPLE

During the 3 months of data collection, 7129 workers were interviewed and 94 refused to participate. So 7035 questionnaires were completed and 7010 were eligible for analysis. The description of the sample is presented in table 1.

The sample consisted of 3842 men $(54.8 \%)$ and 3168 women $(45.2 \%)$. The mean age was 37.8 years in men (SD 10, range $15-73$ years), significantly higher than in women $: 37.0$ years (SD 11, range 16-72 years). Weight and height were higher in men and mean BMI was significantly higher in men than in women: $24.6 v$ 23.3 ( $\mathrm{p}<0.001)$.

Although most workers were right handed ( $87 \%$ of men and $90 \%$ of women), the prevalence of left handed and ambidextrous subjects was significantly higher in men: $8 \% v$ $7 \%$ and $5 \%$ v $4 \%$. Men had a significantly higher mean number of children (1.42) in their families than women (1.21), (range 0-9 for both sexes).

There were more smokers among men $(46.5 \%)$ than among women $(37.7 \%)$. Regular 
Table 2 Low back pain during the previous 12 months (\%): classification, medical, and social conseqences

\begin{tabular}{llll}
\hline & $\begin{array}{c}\text { Men } \\
n=2023\end{array}$ & $\begin{array}{c}\text { Women } \\
n=1833\end{array}$ & $p$ Value \\
\hline Mild cases (without referred pain) & 67.3 & 60.5 & $<0.001^{\star}$ \\
Moderate cases (with referred pain above the knee) & 20.0 & 21.9 & $<0.001^{\star}$ \\
Serious cases (with referred pain below the knee) & 12.7 & 17.6 & $<0.001^{\star}$ \\
Low back symptoms for $>8$ days & 52.3 & 60.2 & $<0.001$ \\
Consultation of health care providers (physician, & & & \\
$\quad$ physiotherapist, or other specialist) & 31.1 & 37.1 & $<0.001$ \\
Medication & 36.7 & 46.3 & $<0.001$ \\
Admission to hospital & 4.9 & 4.8 & N.s. \\
Reduction of leisure activities & 26.0 & 27.1 & N.s. \\
Reduction of occupational actvities & 12.0 & 12.0 & N.s. \\
Work station enhancement & 2.8 & 3.6 & N.s. \\
Change of work station & 2.2 & 1.7 & N.s. \\
Change of job & 2.2 & 0.8 & $<0.001$ \\
Stopped work & 9.2 & 10.2 & N.s. \\
Sick leave & 6.9 & 9.1 & $<0.001$ \\
Occupational injury leave & 2.3 & 1.1 & $<0.001$ \\
Leave 1-7 days & 4.2 & 5.0 & N.s. \\
Leave 8-30 days & 3.8 & 3.9 & N.s. \\
Leave $>$ 30 days & 1.4 & 1.5 & N.S. \\
\hline
\end{tabular}

^Overall comparison.

physical exercise was more often reported by men $(35.7 \%)$ than women $(29.6 \%, \mathrm{p}<0.001)$.

Driving time was more frequent and driving time was longer in men. In both sexes, the equal frequency of driving time $<2$ hours probably corresponds to the time to get to and from work.

Main function and hierarchical position in the current job were very different according to sex. Main tasks with a handling component occurred more often in men $(49.5 \% v 19.6 \%)$, as were qualified or management jobs $(67.9 \%$ in men $v 34.8 \%$ in women); $53 \%$ of women were clerks.

The mean duration in the occupation was about 10 years in each sex, but was significantly higher in men $(10.0 v 9.4$ years, $\mathrm{p}<0.01)$.

Work hours a week were significantly higher in men (42.8 (SD 8, range 6-98) hours) than in women (38.0 (SD 8, range 2-80) hours).

Men more often manually lifted weights $>10$ $\mathrm{kg}$. Men more often reported uncomfortable working positions $(34.3 \%$ v $31.9 \%, \mathrm{p}<0.05)$.
Means to achieve good quality work were slightly more often among men $(74.6 \% v$ $73.3 \%$ ), but the difference was not significant.

LOW BACK PAIN DURING THE PREVIOUS 12 MONTHS

During the previous 12 months, 3856 workers reported low back symptoms (back ache, pain, discomfort) and these symptoms concerned men less often than women $(52.7 \% v 58.2 \%)$; the difference was highly significant $(\mathrm{p}<0.001)$. Classification of low back pain and its medical and social consequences during the previous 12 months are shown in table 2 .

Women were more often serious cases.

Admission to hospital for low back pain was neither often nor different between sexes. On the other hand, duration of pain was longer and treatment was highly significantly more often among women.

Only 258 workers (146 men and 112 women) had occupational consequences (work station enhancement, change of work station, change of job).

Social consequences were similar in both sexes except for change of job, which occurred more often among men, compensation for sick leave, which occurred more often among women, and compensation for occupational injury leave, which occurred more often among men.

Non-conditional logistic regression results on the occurrence of low back pain separately in men and women and in the whole sample are shown in table 3.

We included all variables in the regression model except for right or left handedness, which does not seem to be a risk indicator. We also excluded function and hierarchical position because they are not representative of the real work activity and some categories were represented by insufficient numbers.

Table 3 Low back pain: risk factors

\begin{tabular}{|c|c|c|c|c|c|c|c|c|c|}
\hline & \multicolumn{3}{|c|}{$\operatorname{Men}(n=3746)$} & \multicolumn{3}{|c|}{ Women $(n=3081)$} & \multicolumn{3}{|c|}{ Whole sample $(n=6827)$} \\
\hline & p Value & $O R$ & $95 \% C I$ & $p$ Value & $O R$ & $95 \% C I$ & $p$ Value & $O R$ & $95 \% C I$ \\
\hline Sex & & & & & & & $<0.001^{\star}$ & & \\
\hline Women & & & & & & & & 1 & \\
\hline Men & & & & & & & & 0.54 & 0.47 to 0.63 \\
\hline Smoking habit & $<0.05^{\star}$ & & & $<0.05^{\star}$ & & & $<0.01^{\star}$ & & \\
\hline Non-smoking & & 1 & & & 1 & & & 1 & \\
\hline Smoking & & 1.15 & 1.01 to 1.32 & & 1.21 & 1.03 to 1.41 & & 1.17 & 1.06 to 1.30 \\
\hline Driving time/day $(\mathrm{h})$ & $<0.001^{\star}$ & & & NS & & & $<0.001^{\star}$ & & \\
\hline No & & 1 & & & 1 & & & 1 & \\
\hline$<2$ & & 1.31 & 1.10 to 1.56 & & 1.02 & 0.87 to 1.20 & & 1.13 & 1.01 to 1.27 \\
\hline $2-4$ & & 1.66 & 1.34 to 2.05 & & 1.23 & 0.89 to 1.70 & & 1.43 & 1.21 to 1.69 \\
\hline$>4$ & & 1.61 & 1.24 to 2.09 & & 0.47 & 0.23 to 0.97 & & 1.26 & 1.01 to 1.59 \\
\hline Manual weight lifting $>10 \mathrm{~kg}$ & $<0.05^{\star}$ & & & $<0.001^{\star}$ & & & $<0.001^{\star}$ & & \\
\hline Never & & 1 & & & 1 & & & 1 & \\
\hline$<$ Once/week & & 1.23 & 1.01 to 1.53 & & 1.35 & 1.04 to 1.75 & & 1.30 & 1.10 to 1.53 \\
\hline$\geqslant$ Once/week & & 1.20 & 1.01 to 1.44 & & 1.62 & 1.25 to 2.10 & & 1.33 & 1.15 to 1.55 \\
\hline Every day & & 1.27 & 1.06 to 1.53 & & 1.69 & 1.27 to 2.25 & & 1.37 & 1.18 to 1.59 \\
\hline Uncomfortable working positions & $<0.001^{\star}$ & & & $<0.001^{\star}$ & & & $<0.001^{\star}$ & & \\
\hline Yes & & 1 & & & 1 & & & 1 & \\
\hline No & & 0.54 & 0.46 to 0.63 & & 0.49 & 0.41 to 0.59 & & 0.51 & 0.46 to 0.58 \\
\hline Means to achieve good quality work & $<0.001^{\star}$ & & & $<0.001^{\star}$ & & & $<0.001^{\star}$ & & \\
\hline Yes & & 1 & & & 1 & & & 1 & \\
\hline No & & 1.39 & 1.19 to 1.63 & & 1.38 & 1.15 to 1.65 & & 1.39 & 1.24 to 1.57 \\
\hline Age $(y)$ & NS & 1.00 & 0.99 to 1.01 & $<0.05^{\star}$ & 0.98 & 0.97 to 0.99 & NS & 0.99 & 0.99 to 1.00 \\
\hline Children (n) & NS & 0.97 & 0.92 to 1.03 & $<0.05^{\star}$ & 1.11 & 1.03 to 1.20 & NS & 1.02 & 0.98 to 1.07 \\
\hline Duration of job (y) & $<0.001^{\star}$ & 0.98 & 0.97 to 0.99 & NS & 1.00 & 0.99 to 1.01 & NS & 0.99 & 0.98 to 1.00 \\
\hline
\end{tabular}


Table 4 Low back pain with or without referred pain: risk factors

\begin{tabular}{|c|c|c|c|c|c|c|c|c|c|}
\hline & \multicolumn{3}{|c|}{ Men $(n=1970)$} & \multicolumn{3}{|c|}{ Women $(n=1775)$} & \multicolumn{3}{|c|}{ Whole sample $(n=3745)$} \\
\hline & $p$ Value & $O R$ & $95 \% C I$ & $p$ Value & $O R$ & $95 \% C I$ & p Value & $O R$ & $95 \% C I$ \\
\hline Sex & & & & & & & $<0.001^{\star}$ & & \\
\hline Women & & & & & & & & 1 & \\
\hline Men & & & & & & & & 0.50 & 0.41 to 0.62 \\
\hline Smoking habit & NS & & & $<0.001^{\star}$ & & & $<0.05^{\star}$ & & \\
\hline Non-smoking & & 1 & & & 1 & & & 1 & \\
\hline Smoking & & 0.98 & 0.80 to 1.19 & & 1.49 & 1.21 to 1.84 & & 1.19 & 1.03 to 1.38 \\
\hline Driving time/day $(\mathrm{h})$ & NS & & & NS & & & NS & & \\
\hline No & & 1 & & & 1 & & & 1 & \\
\hline$<2$ & & 1.01 & 0.76 to 1.33 & & 1.08 & 0.88 to 1.33 & & 1.04 & 0.88 to 1.23 \\
\hline $2-4$ & & 1.17 & 0.85 to 1.60 & & 0.93 & 0.61 to 1.41 & & 1.10 & 0.88 to 1.39 \\
\hline$\geqslant 4$ & & 1.15 & 0.79 to 1.67 & & 1.55 & 0.54 to 4.44 & & 1.15 & 0.84 to 1.57 \\
\hline Manual weight lifting $>10 \mathrm{~kg}$ & NS & & & NS & & & NS & & \\
\hline Never & & 1 & & & 1 & & & 1 & \\
\hline$<$ Once/week & & 1.16 & 0.85 to 1.60 & & 1.09 & 0.79 to 1.51 & & 1.15 & 0.92 to 1.44 \\
\hline$\geqslant$ Once/week & & 1.22 & 0.93 to 1.61 & & 1.17 & 0.86 to 1.58 & & 1.22 & 1.00 to 1.49 \\
\hline Every day & & 0.96 & 0.73 to 1.27 & & 1.33 & 0.97 to 1.82 & & 1.06 & 0.87 to 1.30 \\
\hline Uncomfortable working positions & NS & & & $<0.01^{\star}$ & & & $<0.001^{\star}$ & & \\
\hline Yes & & 1 & & & 1 & & & 1 & \\
\hline No & & 0.83 & 0.66 to 1.05 & & 0.70 & 0.56 to 0.87 & & 0.76 & 0.65 to 0.89 \\
\hline $\begin{array}{l}\text { Means to achieve good quality } \\
\text { work }\end{array}$ & NS & & & NS & & & NS & & \\
\hline Yes & & 1 & & & 1 & & & 1 & \\
\hline No & & 0.95 & 0.77 to 1.19 & & 1.01 & 0.81 to 1.26 & & 0.99 & 0.85 to 1.16 \\
\hline Age $(y)$ & $<0.05^{\star}$ & 1.01 & 1.004 to 1.03 & $<0.001^{\star}$ & 1.02 & 1.0091 to 1.0363 & $<0.001^{\star}$ & 1.02 & 1.01 to 1.03 \\
\hline Children (n) & $<0.05^{\star}$ & 1.08 & 1.005 to 1.17 & NS & 1.06 & 0.96 to 1.16 & $<0.05^{\star}$ & 1.08 & 1.01 to 1.14 \\
\hline Duration of job (y) & $<0.01^{\star}$ & 1.02 & 1.005 to 1.033 & NS & 1.01 & 0.99 to 1.02 & $<0.01^{\star}$ & 1.015 & 1.005 to 1.025 \\
\hline Working time (h/week) & $<0.05^{\star}$ & 1.01 & 1.0004 to 1.0251 & NS & 1.003 & 0.99 to 1.01 & $<0.05^{\star}$ & 1.009 & 1.0003 to 1.0179 \\
\hline
\end{tabular}

RESULTS OF LOGISTIC REGRESSION ON THE PRESENCE OR ABSENCE OF LOW BACK PAIN Among the 6827 workers included in the logistic model, low back pain occurred significantly more often among women, and among workers of both sexes reporting manual lifting of weights $>10 \mathrm{~kg}$, uncomfortable working positions, driving, absence of means to achieve good quality work, and smoking. The risk of developing low back pain increased with the frequency of manual lifting of weights $>10 \mathrm{~kg}$ and with driving time. Driving was a risk factor only among men. The number of children was a risk factor only among women: (one child, odds ratio (OR) 1.11, two children, OR 1.23, three children, OR 1.36). This statistical method does not seem to be realistic for more than three children.

Working time in hours a week, regular physical exercise, and BMI were not significantly correlated with low back pain.
Non-conditional logistic regression results for the incidence of low back pain with referred pain above or below the knee are shown in table 4 .

RESULTS OF LOGISTIC REGRESSION FOR LOW BACK PAIN WITH OR WITHOUT REFERRED PAIN

Among the 3745 workers with low back pain included in the logistic model, low back pain with referred pain above or below the knee was associated with female sex, aging, uncomfortable working positions, number of years at the job, number of children, smoking habit, and work time a week in hours. Regular physical exercise and BMI were not significantly correlated. When analysed by sex, only aging remained a risk factor common to men and women. Uncomfortable working positions and smoking habit were identified as factors associated with low back pain with referred pain only among women. Among men, factors associated with low back pain with referred pain were

Table 5 Occupational consequences: risk factors

\begin{tabular}{|c|c|c|c|c|c|c|c|c|c|}
\hline & \multicolumn{3}{|c|}{$\operatorname{Men}(n=1970)$} & \multicolumn{3}{|c|}{ Women $(n=1775)$} & \multicolumn{3}{|c|}{ Whole sample $(n=3745)$} \\
\hline & $p$ Value & OR & $95 \% C I$ & $p$ Value & OR & $95 \% C I$ & $p$ Value & OR & $95 \% C I$ \\
\hline Sex & & & & & & & N.S. & & \\
\hline Women & & & & & & & & 1 & \\
\hline Men & & & & & & & & 0.90 & 0.58 to 1.40 \\
\hline Manual weight lifting $>10 \mathrm{~kg}$ & $<0.01^{\star}$ & & & NS & & & NS & & \\
\hline Never & & 1 & & & 1 & & & 1 & \\
\hline$<$ Once/week & & 1.47 & 0.68 to 3.22 & & 0.71 & 0.33 to 1.53 & & 0.98 & 0.58 to 1.66 \\
\hline$\geqslant$ Once/week & & 1.61 & 0.84 to 3.12 & & 1.25 & 0.68 to 2.27 & & 1.28 & 0.84 to 2.00 \\
\hline Every day & & $2.77^{\star}$ & 1.51 to 5.26 & & 0.60 & 0.30 to 1.22 & & 1.47 & 0.97 to 2.22 \\
\hline Uncomfortable working positions & NS & & & $<0.05^{\star}$ & & & NS & & \\
\hline Yes & & 1 & & & 1 & & & 1 & \\
\hline No & & 1.03 & 0.64 to 1.66 & & 0.57 & 0.35 to 0.93 & & 0.78 & 0.55 to 1.09 \\
\hline Age (y) & $<0.05^{\star}$ & 1.04 & 1.01 to 1.06 & $<0.01^{\star}$ & 1.04 & 1.01 to 1.07 & $<0.001^{\star}$ & 1.04 & 1.02 to 1.06 \\
\hline Type of pain & $<0.001^{\star}$ & & & $<0.01^{\star}$ & & & $<0.001^{\star}$ & & \\
\hline Without referred pain & & 1 & & & 1 & & & 1 & \\
\hline With referred pain & & 3.22 & 2.10 to 4.95 & & 1.93 & 1.22 to 3.04 & & 2.48 & 1.82 to 3.38 \\
\hline Duration of pain (days) & $<0.001^{\star}$ & & & $<0.05^{\star}$ & & & $<0.001^{\star}$ & & \\
\hline Everyday & & 1 & & & 1 & & & 1 & \\
\hline$>30$ & & 0.62 & 0.33 to 1.17 & & 0.56 & 0.28 to 1.08 & & 0.57 & 0.37 to 0.90 \\
\hline $8-30$ & & 0.43 & 0.23 to $0.83^{\star}$ & & 0.41 & 0.21 to $0.81^{\star}$ & & 0.42 & 0.26 to 0.66 \\
\hline $1-7$ & & 0.19 & 0.09 to $0.38^{\star}$ & & 0.34 & 0.17 to $0.69^{\star}$ & & 0.25 & 0.15 to 0.40 \\
\hline
\end{tabular}


number of years at the job, number of work hours a week, and number of children.

Non-conditional logistic regression results for low back pain with occupational consequences compared with low back pain without occupational consequences are shown in table 5.

RESULTS OF LOGISTIC REGRESSION FOR LOW BACK PAIN WITH OR WITHOUT OCCUPATIONAL CONSEQUENCES

Sex did not seem to be a risk factor among workers with low back pain and occupational consequences (change of job, change of work station, work station enhancement). We found the following associated factors: referred pain, pain frequency, pain duration, and aging.

Manual lifting of weights $>10 \mathrm{~kg}$ every day was an associated factor among men and uncomfortable working positions was an associated factor among women.

\section{Discussion}

In our sample, low back pain occurred more often and was more severe among women. To be a woman was identified as a risk factor for low back pain in some studies before 1990, but, in her review of the literature, Riihimäcki did not report sex as a risk factor. ${ }^{1}$ More recent studies have also reported contradictory results. In the review by Burdorf and Sorock, sex did not seem to be linked with low back pain. ${ }^{10}$ On the other hand, female sex seemed to be preponderant for the long duration of sick leave related to low back pain in the study of Hemingway et al. ${ }^{11}$ In the study of Park et al, low back pain occurred more often among women except for low back pain caused by occupational injuries or occupational repetitive activities ${ }^{12}$; our results are similar, except for repetitive activities, which were not analysed in our study. Finally, Dempsey et al emphasised the marked sex related differences in job category. ${ }^{13}$ This finding justified our separate analysis by sex. The main differences found were: more manual tasks among men and less qualified jobs or jobs with responsibilities among women. These observations reflect the sex related employment situation in the Paris region $^{14}$ : men drive more often and driving time is longer, have uncomfortable working positions, and manually lift weights $>10 \mathrm{~kg}$. Men traditionally do more transporting and manual handling jobs. Longer work time a week among men is a known sociological phenomenon. ${ }^{14}$ Women more often have part time jobs, allowing them to carry out household tasks and to take care of children. ${ }^{15}$ In our study, we did not assess this extraoccupational work load that nevertheless plays a part in the development of low back pain.

In the first univariate analysis that focused on low back pain during the entire lifetime, women reported low back problems more often than men, but the difference was not significant. ${ }^{7}$ This difference became significant when we examined low back pain during the previous 12 months. Non-conditional logistic regression analysis confirmed female sex as an associated factor of low back pain in our popu- lation of workers performing all kind of activities. The higher incidence of low back pain with referred pain among women, that occurred in our preliminary results, ${ }^{7}$ was also confirmed.

We classified low back pain into three levels of severity according to the presence of referred pain above or below the knee, as recommended by the Canadian experts group. ${ }^{16}$ This classification of severity seemed to be more relevant than duration of sick leave, which is influenced by various psychosocial factors. ${ }^{17-19}$ The influence of psychosocial factors was found in our results, as only $12 \%$ of men and women declared that they were obliged to reduce their work activity, whereas reduction of extraoccupational activities was reported by $27.1 \%$ of women and $26.0 \%$ of men. One hypothesis could be that, in the current unemployment context, workers with low back pain give priority to their job at the expense of their private activities.

The more frequent severity among women explains their more frequent use of health care facilities: consultation with healthcare providers and consumption of medication for low back problems.

The risk factors for low back pain found in this study are already known - manual lifting of weights $>10 \mathrm{~kg},{ }^{101213}$ uncomfortable working positions, ${ }^{17102021}$ driving time, ${ }^{135}$ absence of means to achieve good quality work,, ${ }^{13} 51013202223$ and smoking. ${ }^{4}$ As expected, manual handling tasks, uncomfortable working positions, and driving were found not to be associated with occupational consequences. These factors could be present in the worker's occupational history, before the onset of low back pain, but, by definition, workers with low back pain and occupational consequences are either no longer exposed to these risk factors, or only at a much lower degree.

The composition of our sample was representative of the working population of private companies in the Paris region according to age, sex, and socio-occupational group. ${ }^{14}$ It is natural to find higher mean values among men than among women for weight, height, and BMI, based on these data. The higher prevalence of smokers among men is a known phenomenon. The greater mean number of children for families of men than for working women is explained by socio-occupational factors: women with a lot of children at home tend to stop work to care for their children. ${ }^{15}$

It could seem surprising to find the number of children as a risk factor (OR 1.11 for one child) only among women, although in our sample, they had fewer children than families of men. The observed association between the number of children and low back pain among women probably also involves household activity, not assessed in this study. ${ }^{15}$ Finkelstein found a link between low back pain and the number of children among firemen and policemen in Ontario ${ }^{24}$ and presumed that this link had to be attributable to leisure activities with children. In our study, we found the number of children to be a factor associated with low back pain with referred pain among men ( OR 1.08 for one child). 
Tsai et al, like ourselves, identified smoking as a factor associated with low back pain. ${ }^{4}$ In our study, smoking seemed to be associated with low back pain with referred pain in women.

In her reflection about the future challenges in epidemiological research into musculoskeletal diseases, Riihimäcki suggested that only severe cases should be considered despite their low incidence. ${ }^{25}$ We found 578 serious cases out of 3856 cases of low back pain during the previous 12 months. Ageing was a risk factor only among women for low back pain with referred pain above and below the knee. As most women of our sample were clerks (53\%), uncomfortable working position was again found to be a risk factor in sedentary jobs, as emphasised by Burdorf et al. ${ }^{21}$ On the other hand, only aging seemed to be linked to serious cases in both men and women. This result is disappointing in terms of prevention, as there is no way in which we can act on this factor. Serious cases are certainly important for the economy as Hashemi et al showed that $10 \%$ of cases of low back pain, probably serious cases, generate $86 \%$ of health costs related to low back pain. ${ }^{26}$ Hadler showed that this cost could be decreased if physicians prescribed fewer medications to cure the symptom in favour of psychosociological intervention. ${ }^{27}$

Serious cases have not only a high economic cost (admission to hospital), but also a heavy social cost: the 203 cases of low back pain with occupational consequences were serious cases, affecting older workers.

Our study, carried out in workers employed in all types of jobs, showed aging as a main risk factor for severity of low back pain. Nurminen also found aging to be a risk factor among building workers exposed to a heavy physical work load. ${ }^{28}$ The main prevention issue is to assess occupational risk factors involved before aging. Riihimäcki discussed the difficulty of such an assessment. ${ }^{25}$ Direct observation of movements and working positions of workers seems to be the best assessment method to evaluate postural load on the low back. ${ }^{29}$ This method is better than self administered questionnaires on physical work load. ${ }^{30}$ However, in practice, it is impossible to obtain such observations over the entire working life.

Based on this analysis of our data by sex, the incidence and severity of low back pain were higher in women although women seemed to be less exposed to known occupational risk factors. However, our results indicate a higher weighting of these risk factors among female workers according to OR values. Each year, occupational physicians of the Paris region visit and study all work places to recommend improvements to working conditions. Particular attention must therefore be paid by occupational physicians to lifting of weights and uncomfortable working positions in female jobs (clerks, trading, health care staff).

We gratefully acknowledge Mrs Annette Leclerc (INSERM U88, Saint Maurice, France) for her contribution to the elaboration of this study, for her help throughout the study, and fo her advice about the present analysis.
1 Riihimäcki $\mathrm{H}$. Low back pain, its origin and risk indicators. Scand $\mathcal{F}$ Work Environ Health 1991;17:81-90.

2 Walsh K, Cruddas M, Coggon D. Interaction of height and mechanical loading of the spine in the development of low back pain. Scand $\mathcal{F}$ Work Environ Health 1991;17:420-4.

3 Pietri F, Leclerc A, Boitel L, et al. Low back pain in commercial travellers. Scand $\mathcal{f}$ Work Environ Health 1992;18:52-8.

4 Tsai S, Gilstrap E, Cowles S, et al. Personal and job characteristics of musculoskeletal injuries in an industrial population. F Occup Med 1992;34:606-12.

5 Coste J, Paolaggi JB. Revue critique de l'épidémiologie des lombalgies. Rev Epidemiol Sante Publique 1989;37:371-83.

6 Baldasseroni A, Tartaglia R, Biggeri A, et al. Lombalgia da sforzo : studio caso controllo tra i lavoratori dei servizi sanisforzo : studio caso controllo tra i lavoratori dei servizi sani-

7 Alcouffe J, Brehier M, Dupéry M, et al. Lombalgie chez les salariés des petites et moyennes entreprises de la région parisienne : gravité et conséquences professionnelles. Une enquête descriptive portant sur 7000 salariés . Cahiers Méd Interprof (CAMIP) 1997;445-54.

8 Collas F, Mairiaux P. Travail de montage d'ascenseurs et plaintes musculo-squelettiques. Arch Mal Prof 1992;53: $407-13$.

9 Kuorinka I, Jonsson B, Kilbom A, et al. Standardized Nordic questionnaire for the analysis of musculoskeletal symptoms. Applied Ergonomics 1987;18:233-7.

10 Burdorf A, Sorock F. Positive and negative evidence of risk factors for back disorders. Scand $\mathcal{F}$ Work Environ Health 1997;23:243-56.

11 Hemingway H, Shipley M, Stansfeld S, et al. Sickness absence from back pain, psychosocial work characteristics and employment grade among office workers. Scand $\mathcal{F}$ Work Environ Health 1997;23:121-9.

12 Park C , Wagener D, Parson V. Back pain among US workers: comparison of worker attributes according to selfreported causes of back pain. Int $\mathcal{f}$ Occup Environ Health 1997;3:37-44.

13 Dempsey P, Burdorf A, Webster B. The influence of personal variables on work-related low back disorders and implications for future research. $f$ Occup Environ Med 1997;39:748-59.

14 Insee Annuaire statistique de la France 1991-2. Résultats de 1991. Insee et les services statistiques des Ministères. Paris: 1992;96:54

15 Insee et délégation régionale aux droits des femmes d'Ile de France. Les femmes en Ile de France, faits et chiffres. Insee Direction régionale d'Ile de France. Paris: 1995;191:7-8.

16 Spitzer WO, Le Blanc FE, Dupuis M, et al. Scientific approach to the assessment and management of activityrelated spinal disorders : a monograph for clinicians : report of the Quebec Task Force on Spinal Disorders. Spine 1987; 12:51-9.

17 Infante-Rivard C, Lortie M. Prognostic factors for return to work after a first compensated episode of back pain. Occup Environ Med 1996;53:488-94.

18 Van Der Weide W, Verbeek J H, Van turler M. Vocational outcome of intervention for low-back pain. Scand $\mathcal{F}$ Work Environ Health 1997;23:165-78.

19 Infante-Rivard C, Lortie M. Relapse and short sickness absence for back pain in the six months after return to work. Occup Environ Med 1997;54:328-34.

20 Krause N, Ragland D, Greiner B, et al. Psychosocial job factors associated with back and neck pain in public transit operators. Scand F Work Environ Health 1997;23:179-86.

21 Burdorf A, Naaktgeboren B, De Groot H. Occupational risk factors for low back pain among sedentary workers. $\mathcal{f}$ Occup Med 1993;35:1213-20.

22 Houtman I, Bongers P, Smulders P, et al. Psychosocial stressors at work and musculoskeletal problems. Scand $\mathcal{F}$ Work Environ Health 1994;20:139-45.

23 Toomingas A, Theorell T, Michelsen $\mathrm{H}$, et al. Associations between self rated psychosocial work conditions and musculoskeletal symptoms and signs. Scand $\mathcal{f}$ Work Environ Health 1997;23:130-9.

24 Finkelstein M. Back pain and parenthood. Occup Environ Med 1995;52:51-3.

25 Riimäcki H. Hands up or back to work: future challenges in epidemiologic research on musculoskeletal diseases. Scand f Work Environ Health 1995;21:401-3.

26 Hashemi L, Webster B, Clancy E, et al. Length of disability and cost of workers compensation low back pain claims. $\mathcal{F}$ Occup Environ Med 1997;39:937-45.

27 Hadler N. Regional back pain: predicament at home, nemesis at work. F Occup Environ Med 1996;38:973-8.

28 Nurminen M. Reanalysis of the occurrence of back pain among construction workers modelling for the interdependent effects of heavy physical work, earlier back accidents, and aging. Occup Environ Med 1997;54:807-11.

29 Burdorf A, Laan J. Comparison of methods for the assessment of postural load on the back. Scand 7 Work Environ Health 1991;17:425-9.

30 Viikari-Juintura E, Rauas S, Martikainen R, et al. Validity of self-reported physical work load in epidemiologic studies on musculoskeletal disorders. Scand $\mathcal{F}$ Work Environ Health 1996;22:251-9 